\title{
PENINGKATAN KINERJA INDUSTRI KECIL DAN MENENGAHDENGAN PENDEKATAN MODEL ERGONOMI POSTUR KERJA
}

\section{Syaeful Arief}

\author{
ProgramStudi Teknik Industri,UniversitasJenderal Ahmad Yani \\ YogyakartaJln.Siliwangi, Ring Road Barat, Gamping, Yogyakarta \\ Email:syaeful.arief87@gmail.com
}

\begin{abstract}
Human factors are very important factors in small and medium industries, in determining the productivity of a production system. However, work safety and comfort are often overlooked, as happened in two different companies, namely food companies and manufacturing companies. Both are influenced by the conditions of the company's work facilities that are less ergonomic, so that they can endanger the body of the worker. A similar thing also happened to Manufacturing companies. This study aims to analyze and make a proposal for a more ergonomic work facility design using the Ergonimi pastoral approach. From the results of the improvement it was found that the risk level of Cumulative Trauma Disorders (CTD) was reduced from high to low and from high to moderate. While productivity of work time increases by 10-20\%.
\end{abstract}

Keywords: Ergonomics, RULA, REBA, CTD and Productivity.

\begin{abstract}
Abstrak
Faktor manusia merupakan faktor yang sangat penting dalam Industri kecil menengah, dalam menentukan produktivitas suatu sistem produksi. Walaupun demikian, keselamatan dan kenyamanan kerja seringkali terabaikan, seperti yang terjadi pada dua perusahaan yang berbeda, yaitu perusahaan makanan dan perusahaan manufaktur. Keduanya dipengaruhi oleh kondisi fasilitas kerja perusahaan yang kurang ergonomis, sehingga dapat membahayakan tubuh pekerja. Hal serupa juga terjadi pada perusahaan Manufaktur. Penelitian ini bertujuan untuk menganalisis dan membuat usulan rancangan fasilitas kerja yang lebih ergonomis menggunakan pendekatan Ergonimi pasturkerja. Dari hasil perbaikan didapatkan penurunan tingkat resiko Cumulative Trauma Disorders (CTD) dari tinggi menjadi rendah dan dari tinggi menjadi sedang. Sedangkan produktivitas waktu kerja meningkat sebesar 10-20\%.
\end{abstract}

Katakunci:Ergonomi, RULA, REBA, CTD dan Produktivitas. 


\section{PENDAHULUAN}

Peranan manusia sebagai sumber tenaga masih sangat diperlukan dalam bidang industri, khususnya industri kecil dan menengah. Banyak alasan mengapa tenaga manusia masih digunakan di dalam dunia industri. Fleksibilitas gerakan merupakan alasan kuat penggunaan tenaga manusia, terutama untuk kegiatan penanganan material secara manual (Manual Material Handling) dengan beban kerja yang ringan. Aktivitas penanganan material secara manual (Manual Material Handling) yang terdiri dari mengangkat, menurunkan, mendorong, menarik dan membawa merupakan sumber utama keluhan karyawan di industri.

Aktivitas penanganan material secara manual yang tidak tepat dapat menimbulkan kerugian bahkan kecelakaan pada karyawan. Akibat yang ditimbulkan dari aktivitas penanganan material yang tidak benar salah satunya adalah keluhan muskuloskeletal. Keluhan muskuloskeletal adalah keluhan pada bagian-bagian otot skeletal yang dirasakan oleh seseorang mulai dari keluhan yang sangat ringan sampai sangat sakit. Apabila otot menerima beban statis secara berulang dalam jangka waktu yang lama akan dapat menyebabkan keluhan berupa kerusakan pada sendi, ligamen dan tendon.

Sebagian besar proses pekerjaan pada Industri Kecil Menengah masih dilakukan secara manual. Hal tersebut dikhawatirkan akan terdapat keadaan dimana terjadi postur kerja yang salah. Dari postur kerja yang salah yang dilakukan secara terus menerus, tentunya akan sangat membahayakan bagi keselamatan pekerja. Proses produksi pada Industri Kecil dan Menengah (IKM) didominasi oleh aktivitas penanganan material dan pekerjaan ringan, dimana seluruhnya dilakukan secara manual. Dari kondisi tersebut maka hampir seluruh tubuh operator digunakan untuk melakukan aktivitas kerja. Dengan demikian dikhawatirkan akan menyebabkan gangguan muskuloskeletal. Sehingga diperlukan suatu metode yang dapat digunakan untuk menganalisis proses penanganan material tersebut secara lebih detail, untuk mengurangi gangguan muskuloskeletal tersebut.

Selanjutnya, menurutInternational Labor

Organization

menyatakanbahwasannyaergonomimerupakanilm uterapan

yang

mempelajarihubunganbiologimanusiadenganilmut eknikbagipekerja dan lingkungankerjanya. Pendekatanergonomidilakukansupayamenghasilka nkepuasankerja yang maksimal dan dapatmeningkatkanproduktivitas.

Metode Ovako Working Posture Analysis System (OWAS) merupakan metode yang mengevaluasi dan menganalisa sikap kerja yang tidak nyaman dan berakibat pada cidera muskuloskeletal. Bagian sikap kerja yang diamati meliputi pergerakan bagian tubuh dari punggung, bahu, tangan dan kaki. Metode OWAS sangat tepat diaplikasikan pada analisis produksi perusahaan Pedro karena terdapat aktivitas-aktivitas produksi perusahaan yang kurang memenuhi tingkat keamanan dan kenyamanan.

Sedangkan metode Rapid Entire Body Assessment (REBA) merupakan metode yang dikembangkan dalam bidang ergonomi dan dapat digunakan secara cepat untuk menilai posisi kerja atau postur kerja operator. Postur kerja yang diamati adalah leher, punggung, lengan, pergelangan tangan dan kaki seorang operator. Sehingga metode OWAS dan REBA sangat sesuai dengan penelitian tentang postur kerja yang mencakup pergerakan tubuh secara keseluruhan.

RULA atauRapid Upper Limb Assessment merupakanmetodeuntukmenilaiposisikerja yang dilakukan oleh tubuhbagianatas. Metodeinidikembangkanuntukmenyelidikiresikok elainan yang akandialami oleh seorangpekerjadalammelakukanaktivitaskerja yang memanfaatkananggotatubuhbagianatas. Metodeinimenyediakansebuahperhitungantingkata knbebanmuskuloskeletaldi dalampekerjaan yang memilikiresiko pada bagiantubuhdariperuthinggaleher.

Pengumpulan data dilakukan dengan melakukan studi lapangan, berupa observasi dan wawancara terhadap responden untuk mendapatkan data yang diinginkan. Data tersebut adalah data postur kerja 
Vol.3.No.1 Agustus 2019

berupa rekaman gambar pada saat operator melakukan aktivitas material handlingmaupun kerja manual. Selanjutnya dilakukan pengolahan data dengan menggunakan metode OWAS, REBA, RULA, dan analisis Biomekanika.

Adapun elemen yang diamati pada penelitian menggunakan metode. OWAS adalah penilaian postur kerja yang meliputi sikap punggung, lengan, kaki, dan faktor beban. Sedangkan pada metode REBA meliputi penilaian postur kerja pada sikap punggung, leher, kaki, lengan atas, lengan bawah, pergelangan tangan dan faktor tambahan. Adapun faktorresikopostur, kontraksiotot dan gaya yang digunakanuntuksuatupekerjaantertentu akan dinilai dengan metode RULA. Output yang didapat berupa kategori action level. Setelah pengolahan data yang dilakukan, maka dapat diketahui nilai dari action level yang akan digunakan sebagai rekomendasi untuk dilakukannya perbaikan.

Selain itu, ketiga pendekatan ergonomi diatas akan dipade dengan konsep Biomekanika untuk menilai beban kerja yang harus ditanggung oleh Tubuh dari pekerja yang bersangkutan. Biomekanika adalah ilmu pengetahuan yang menerapkan hukum-hukum mekanika terhadap struktur hidup, terutama sistem lokomotor dari tubuh. (lokomotor=kegiatan dimana seluruh tubuh bergerak karena tenaganya sendiri dan umumnya dibantu oleh gaya beratnya).

Dari penelitian ini diharapkan dapat memberikan suatu peniaian seberapa jauh Perbaikan Postur Kerja (Dengan pendekatan REBA, RULA, Biomekanika dan OWAS) dapat meningkatkan kinerja Industri Kecil dan Menengah.

\section{METODELOGI PENELITIAN}

Prosedur dalam penelitian ini adalah sebagai berikut :

1.Pengukuran Sudut Tubuh Operator. Pengambilan data berupa sudut-sudut yang dibentuk oleh tubuh operator ketika melakukan seluruh proses produksi, alat yang digunakan yaitu kamera digital, yang kemudian akan diaplikasikan ke dalam software Corel Draw X4 untuk mengetahui sudut-sudutnya. Data postur tubuh yang diambil sebanyak 5 kali dari setiap proses. 
lebarmejasenilai

71,91

$\mathrm{cm}$,

dan

tinggimejadengannilai $80,43 \mathrm{~cm}$.

Tabe. 3.2. Perancangan Kursi untuk Proses Pemanasan

\begin{tabular}{|l|l|c|c|c|c|}
\hline \multicolumn{1}{|c|}{$\begin{array}{c}\text { Dimensi } \\
\text { produk }\end{array}$} & $\begin{array}{c}\text { VariabelAnthropometr } \\
i\end{array}$ & $\begin{array}{c}\text { Mean } \\
\text { Dimensi } \\
\text { Antropometr } \\
\mathrm{i}\end{array}$ & $\begin{array}{c}\text { Persenti } \\
1\end{array}$ & $\begin{array}{c}\text { Ukura } \\
\mathrm{n}(\mathrm{cm})\end{array}$ \\
\hline \multirow{2}{*}{$\mathrm{di}$} & $\begin{array}{l}\text { Tinggi } \\
\text { kursi }\end{array}$ & Tinggi popliteal (Tpo) & 44,29 & $\mathrm{P}_{50}$ & 44,29 \\
\cline { 2 - 6 } & Allowance tinggibusa & 4 & & 4 \\
\hline $\begin{array}{l}\text { Lebarkurs } \\
\mathrm{i}\end{array}$ & Lebarpinggul (Lp) & 31,54 & $\mathrm{P}_{95}$ & 37,37 \\
\hline
\end{tabular}

III. HASIL DAN PEMBAHASAN

Pembahasanpenelitian

perusahaanpengolahantempe

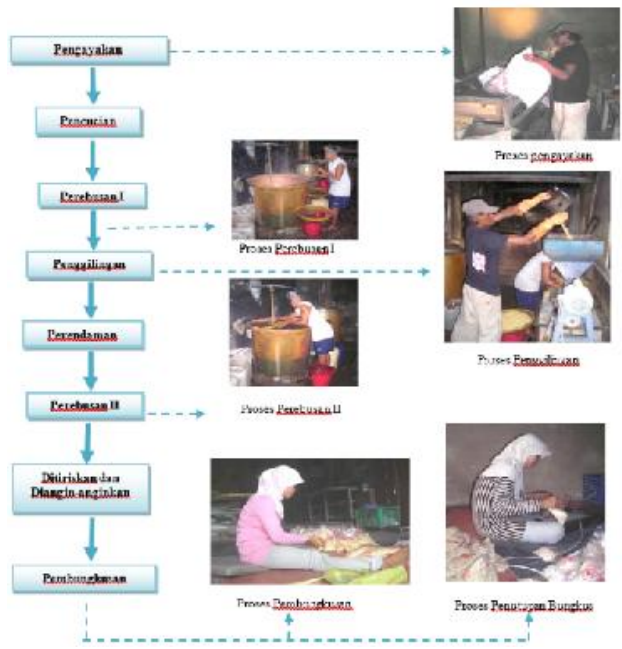

Gambar 3.1. Proses Pengolahan

\section{PenentuanUkuranFasilitas}

Untuk Analisis REBA (Pada Operasi Penutupan Bungkus)Penentuan ukuran fasilitas untuk analisis REBA adalah untuk perancangan fasilitas proses penutupan bungkus. Adapun ukuran dari fasilitas tersebut dapat dilihat pada tabel 4.15.

Tabel 3.15. PerancanganMejauntuk Proses PenutupanBungkus

\begin{tabular}{|c|c|c|c|c|}
\hline $\begin{array}{l}\text { Dimensi } \\
\text { produk }\end{array}$ & $\begin{array}{c}\text { VariabelAnthropome } \\
\text { tri }\end{array}$ & $\begin{array}{c}\text { Mean } \\
\text { Dimensi } \\
\text { Antropomet } \\
\text { ri }\end{array}$ & $\begin{array}{c}\text { Persent } \\
\text { il }\end{array}$ & $\begin{array}{l}\text { Ukura } \\
\text { n (cm) }\end{array}$ \\
\hline $\begin{array}{c}\text { Panjang } \\
\text { meja }\end{array}$ & Rentangantangan (Rt) & 165,58 & $\mathrm{P}_{5}$ & 153,40 \\
\hline $\begin{array}{c}\text { Lebarmej } \\
\text { a }\end{array}$ & Jangkauantangan (Jt) & 78,67 & $\mathrm{P}_{5}$ & 71,91 \\
\hline \multirow{4}{*}{$\begin{array}{l}\text { Tinggi } \\
\text { meja }\end{array}$} & $\begin{array}{l}\text { Tinggi popliteal } \\
\text { (Tpo) }\end{array}$ & 44,29 & $\mathrm{P}_{50}$ & 44,29 \\
\hline & $\begin{array}{l}\text { Tinggi siku duduk } \\
\text { (Tsd) }\end{array}$ & 23,70 & $\mathrm{P}_{5}$ & 19,87 \\
\hline & Tebalpaha (Tp) & 13,90 & $\mathrm{P}_{95}$ & 16,27 \\
\hline & \multicolumn{3}{|c|}{ Total tinggi } & $\begin{array}{c}80,4 \\
3\end{array}$ \\
\hline
\end{tabular}

\section{Pada}

perancanganmejauntukoperasipenutupanbungkus menggunakanvariabelanthropometriRentangantan gan (Rt), Jangkauantangan (Jt), Tinggi popliteal (Tpo), Tinggi siku duduk (Tsd) dan Tebalpaha (Tp).

Setelah dilakukanpenghitungandenganpenyesuaianpersent il, makadidapatkanpanjangmejasenilai $153,40 \mathrm{~cm}$,
Perancangankursi pada operasipemanasanbungkusmenggunakanvariabel $a$ nthropometritinggi popliteal (Tpo), dan lebarpinggul $\quad(\mathrm{Lp}) . \quad$ Setelah dilakukanpenyesuaianpersentil, makadidapatkannilaitinggikursisebesar 48,29 cm. sedangkanlebarkursisebesar $\quad 37,37 \quad \mathrm{~cm} . \quad$ Pada perancanganukurankursiditambahkanallowancetin ggibusa pada alas kursi. Alas tersebutdigunakanuntukmemberikan rasa nyaman pada pantat operator.

Untuk Analisis OWAS ( Pada Operasi Pembersihan Kulit )

Tabel 3.3. PerancanganKursiuntuk Proses PembersihanKulit

\begin{tabular}{|l|l|c|c|c|}
\hline \multirow{2}{*}{$\begin{array}{c}\text { Dimensi } \\
\text { produk }\end{array}$} & $\begin{array}{c}\text { VariabelAnthropomet } \\
\text { ri }\end{array}$ & $\begin{array}{c}\text { Mean } \\
\text { Dimensi } \\
\text { Anthropometr } \\
i\end{array}$ & $\begin{array}{c}\text { Persenti } \\
1\end{array}$ & $\begin{array}{c}\text { Ukura } \\
\mathrm{n}(\mathrm{cm})\end{array}$ \\
\hline $\begin{array}{l}\text { Tinggi } \\
\text { kursi }\end{array}$ & Tinggi popliteal & 44,29 & $\mathrm{P}_{50}$ & 44,29 \\
\cline { 2 - 5 } & Allowancetinggibusa & 4 & & 4 \\
\hline $\begin{array}{l}\text { Lebarkurs } \\
\mathrm{i}\end{array}$ & Lebarpinggul & 31,54 & $\mathrm{P}_{95}$ & 37,37 \\
\hline
\end{tabular}

Karena

perancangankursiuntukoperasipenutupanbungkus dan untukoperasipembersihankulitadalahsama, makadidapatkannilaitinggikursisebesar 48,29 cm. sedangkanlebarkursisebesar $37,37 \mathrm{~cm}$.

PerancanganBerdasarkan Data Anthropometri 1.PerancangandariOperasiPenutupanBungkus (Hasil Analisis REBA)

Pada proses penutupanbungkusterdapatbeberapaperbaikan yang dilakukan, diantaranyaadalah:

a. Sebelum dilakukan perbaikan,posisi operator adalah duduk di lantai. Kemudian dilakukan perbaikan dengan merancang meja dan kursi sesuai dengan dimensi tubuh operator. Dari posisikerja yang duduk di lantaimakaterdapatkondisidimanaposturkerjate rsebutmembahayakan operator.

b.Dari posisikerjaawalbanyakterdapatkesalahan pada penempatanfasilitas yang digunakanuntuk proses penutupanbungkus. 
Sepertijarakbungkustempe yang terlalujauh dan menyebabkanadanyaperubahanpostur yang cepatsecaraterusmenerus. Sehinggakemudiandilakukanperubahanpenem patanfasilitas yang denganmerubahmetodeaktivitasdenganmengat uralat dan bungkus agar dapatdijangkaudenganmudah oleh operator.

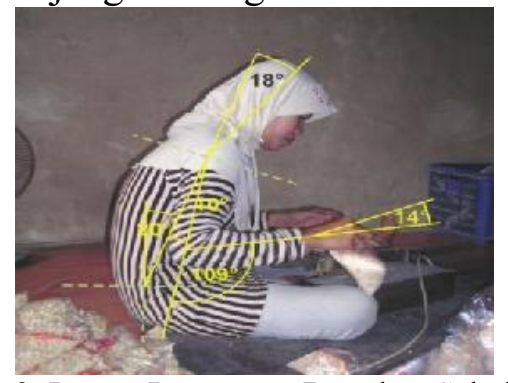

Gambar 3.2. Proses Penutupan Bungkus Sebelum Perbaikan Fasilitas
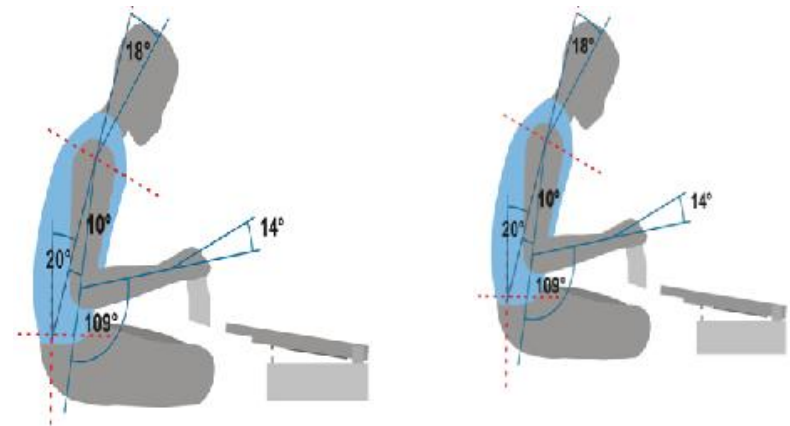

Gambar 3.3. Proses Penutupan Bungkus Sebelum Perbaikan (tampak samping dan atas)

Dari kondisi awal proses penutupan bungkus tersebut kamudian dilakukan perbaikan fasilitas kerja dan metode kerja yang dapat dilihat pada gambar berikut:

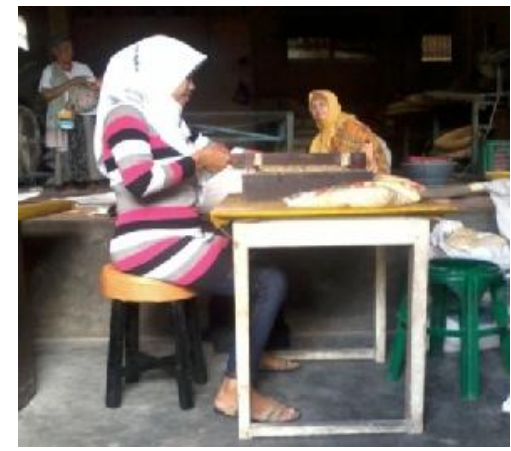

Gambar 3.4. Proses Penutupan Bungkus Setelah Perbaikan Fasilitas

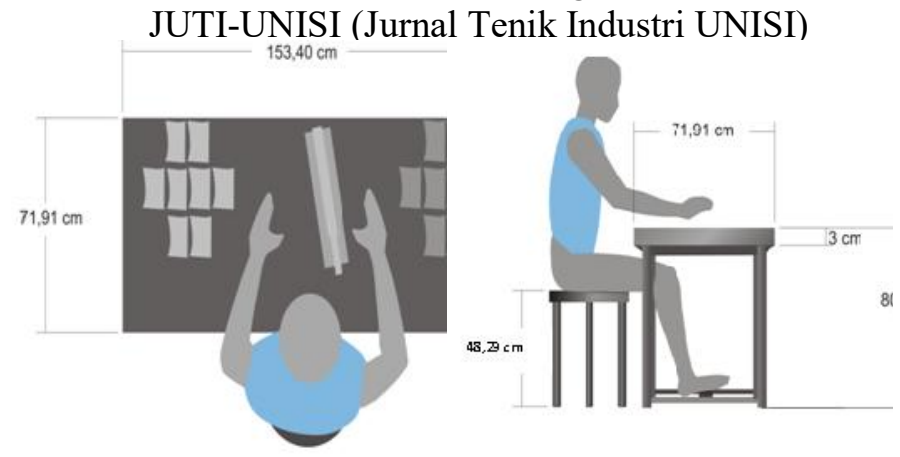

Gambar 3.5. Proses Penutupan Bungkus Setelah Perbaikan Fasilitas (tampak samping dan atas)

2.PerancanganFasilitasdariOperasiPembersihanK ulit (Analisis OWAS)

Pada proses pembersihankulitterdapatbeberapaperbaikan yang dilakukan, diantaranyaadalah:

a.Dengan merancang sebuah kursi yang digunakan oleh operator sesuai dengan dimensi tubuh operator. Sebelum dilakukan perbaikan, operator melakukan aktivitas pembersihan kulit dengan posisi membungkuk. Dari posisi membungkuk terdapat kesalahan postur kerja yang tidak aman. Dari proses kerja tersebut didapatkan keluhan-keluhan diantaranya rasa sakit pada leher, punggung, kaki dan lengan bawah.

b.Pada fasilitas sebelum diperbaiki didapatkan penempatan fasilitas produksi yang kurang tepat. Yaitu pada penempatan tambir besar yang terlalu jauh dari jangkauan, sehingga harus berjalan untuk memindahkan kulit yang telah dikumpulkan pada tambir kecil. Perbaikan yang dilakukan adalah dengan merubah posisi dari tambir besar, yaitu dengan mendekatkan ke operator, Sehingga posisi tambir besar ada pada jangkauan operator, sehingga dapat mengurangi aktivitas operator yang sebelumnya harus berjalan untuk menuju ke tambir besar.

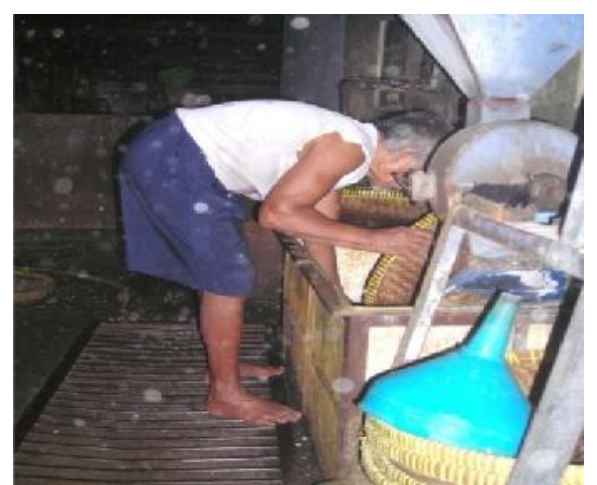

Gambar 3.6. Proses Pembersihan Kulit Sebelum Perbaikan Fasilitas 

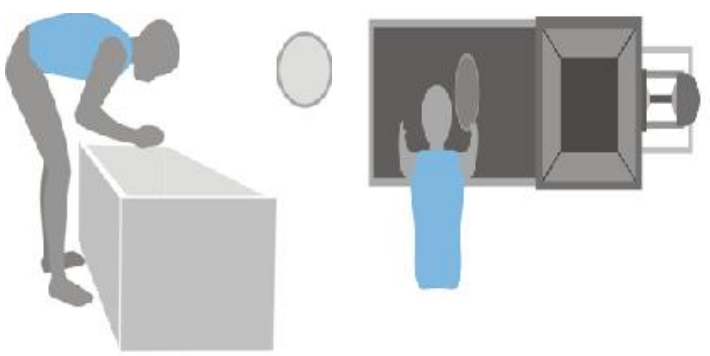

Gambar 3.7. Proses Pembersihan Kulit Sebelum Perbaikan Fasilitas

Dari kondisi proses pembersihan kulit sebelum perbaikan tersebut kemudian dilakukan perbaikan fasilitas kerja dan metode kerja yang dapat dilihat sebagai berikut:

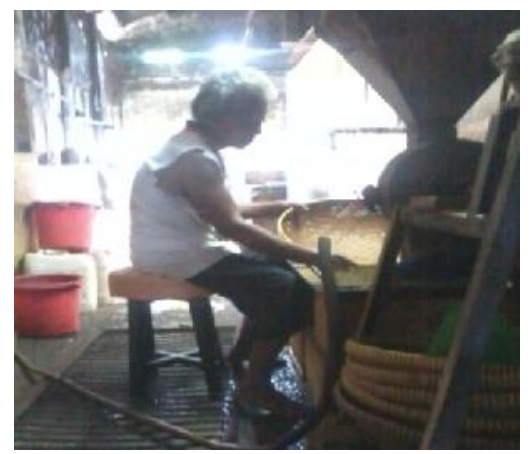

Gambar 3.8. Proses Pembersihan Kulit Setelah Perbaikan Fasilitas
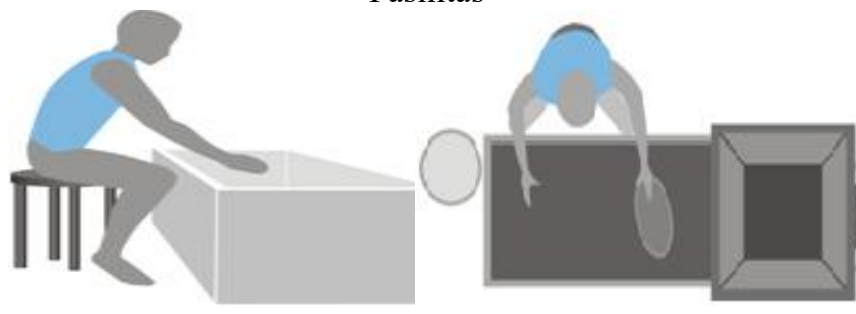

Gambar 3.9. Proses Pembersihan Kulit Setelah Perbaikan Fasilitas (tampak samping dan atas)

\section{Analisis REBA pada PenutupanBungkus}

Dari perbaikanfasilitas pada operasipenutupanbungkus yang dilakukan, kemudiandilakukananalisismenggunakanmetode REBA. Sudut-sudut yang terbentukdariaplikasifasilitas barudapatdilihat pada table 3.4berikut:

Tabel 3.4. Sudut yang Terbentuk Setelah Perbaikan

\begin{tabular}{|c|c|}
\hline $\begin{array}{c}\text { Postur } \\
\text { Tubuh }\end{array}$ & $\begin{array}{c}\text { Sudut yang Terbentuk } \\
\text { Penutupan Bungkus }\end{array}$ \\
\hline Punggung & $7^{0}$ Flexion \\
\hline Leher & $11^{0}$ Flexion \\
\hline Kaki & Duduk \\
\hline $\begin{array}{c}\text { Lengan } \\
\text { Atas }\end{array}$ & $47^{0}$ Flexion \\
\hline $\begin{array}{c}\text { Lengan } \\
\text { Bawah }\end{array}$ & $38^{0}$ Flexion \\
\hline
\end{tabular}

JUTI-UNISI (Jurnal Tenik Industri UNISI)

\begin{tabular}{l|l} 
Pergelangan & $19^{0}$ Flexion
\end{tabular}

Setelah fasilitasbarudiaplikasikan

pada operasipenutupanbungkus,

kemudiandilakukananalisiskembalimenggunakana nalisis REBA untukmengetahuiaction level. Dari analisismetode REBA pada operasipenutupanbungkus, didapatkannilaiaction level sebesar 1 dengan level resikorendah. Dari nilai level resiko yang rendah, makatidakperluadanyaperbaikanlebihlanjut.

\section{Analisis OWAS pada Operasi Pembersihan Kulit}

Dari perbaikan fasilitas pada operasi pembersihan kulit yang dilakukan, kemudian di lakukan analisis menggunakan metode OWAS. Dari penghitungan menggunakan metode OWAS pada operassi pembersihan kulit,dapat diketahui bahwa didapatkan kode OWAS 1113. Sehingga dari tabel OWAS dapat diketahui nilai Action Category sebesar 1 sehingga tidak memerlukan perbaikan.

\section{Analisis Perbandingan Sebelum dan Sesudah Perbaikan}

Dari hasil pengamatan dan penelitian yang dilakukan menggunakan metode REBA maka dapat diketahui hasil dari sebelum dan sesudah perbaikan fasilitas. Dari analisa dapat disimpulkan bahwa terjadi penurunan skor REBA dari pekerjaan penutupan bungkus. Setelah dilakukan aplikasi terhadap kondisi kerja yang ada maka terdapat peningkatan kenyamanan dan keselamatan bagi para pekerja pada operasi penutupan bungkus tersebut.

\section{Perbandingan Skor dari Analisis OWAS}

Dari hasil pengamatan dan penelitian yang dilakukan menggunakan metode OWAS maka dapat diketahui hasil dari sebelum dan sesudah perbaikan fasilitas. Dari analisadapatdiketahuibahwa pada sebelumdilakukanperbaikanfasilitasdidapatkan action perbaikanlangsung, sedangkansetelahperbaikandidapatkan action tidakperluperbaikan. Hal inimenunjukkanbahwanilairesikodariaplikasifasili tas yang baruadalahrendahdibanding pada penggunaanfasilitas yang lama yaitusebelumdilakukanperbaikan.

\section{Perbandingan Produktivitas}


Operasi Penutupan Bungkus (dari analisis REBA) Dari penelitian yang dilakukan, dapat dilakukan pengukuran tentang produktivitas kerja sebelum dan sesudah perbaikan fasilitas. Hasil yang didapatkan dari penghitungan produktivitas kerja dapat dilihat pada tabel berikut:

Tabel 3.9. Perbandingan Produktivitas dari Analisis REBA

\begin{tabular}{|c|c|c|c|}
\hline Pekerjaan & Perbandingan & Sebelum & Sesudah \\
\hline \multirow{2}{*}{$\begin{array}{c}\text { Penutupan } \\
\text { Bungkus }\end{array}$} & Waktu Normal (detik/unit) & 13,03 & 11,51 \\
\cline { 2 - 4 } & Waktu Baku (detik/unit) & 14,59 & 12,89 \\
\cline { 2 - 4 } & Output (unit/detik) & 0,0685 & 0,0775 \\
\hline
\end{tabular}

Dari hasil tersebut maka dapat diketahui peningkatan produktivitas pada operasi penutupan bungkus setelah dilakukan perbaikan fasilitas. Nilai output standar operasi penutupan bungkus sebelum perbaikan adalah 0,0685 unit/detik, sedangkan nilai setelah menggunakan fasilitas baru adalah sebesar 0,0775 unit/detik.

Operasi Pembersihan Kulit (dari analisis OWAS)

Dari penelitian yang dilakukan, dapat dilakukan pengukuran tentang produktivitas kerja sebelum dan sesudah perbaikan fasilitas.

Tabel 3.10. Perbandingan Produktivitas Analisis OWAS

\begin{tabular}{|c|c|c|c|}
\hline Pekerjaan & Perbandingan & Sebelum & Sesudah \\
\hline \multirow{3}{*}{ Pembersihan Kulit } & Waktu Normal (detik/unit) & 30,45 & 27,12 \\
\cline { 2 - 4 } & Waktu Baku (detik/unit) & 34,10 & 30,37 \\
\cline { 2 - 4 } & Output (unit/detik) & 0,0293 & 0,0329 \\
\hline
\end{tabular}

Dari hasil tersebut maka dapat diketahui peningkatan produktivitas pada operasi pembersihan kulit setelah dilakukan perbaikan fasilitas. Dari hasil tersebut maka dapat diketahui peningkatan produktivitas pada operasi pembersihan kulit setelah dilakukan perbaikan fasilitas. Nilai output standar operasi pembersihan kulit sebelum perbaikan adalah 0,0293 unit/detik, sedangkan nilai setelah menggunakan fasilitas baru adalah sebesar 0,0329 unit/detik.

\section{PerbandinganKeluhanKerja}

Setelah dilakukanperbaikankerja, makadapatdilakukanpendataankeluhankerjayaitud enganmemberikankuesionerkepada operator.

Operasi Penutupan Bungkus (dari analisis REBA)Dari hasil kuesioner mengenai keluhan kerja, didapatkan hasil keluhan kerja dari operator sebelum dan sesudah perbaikan fasilitas REBA. Adapunhasilnyadapatdilihat pada tabel 3.11 berikut.
JUTI-UNISI (Jurnal Tenik Industri UNISI)

Tabel 3.11. Perbandingan Keluhan Kerja Operasi Penutupan Bungkus (dari Analisis REBA)

\begin{tabular}{|c|c|c|}
\hline $\begin{array}{c}\text { Persentase } \\
\text { Fasilitas Lama }\end{array}$ & Bagian Tubuh & $\begin{array}{c}\text { Persentase } \\
\text { Fasilitas Baru }\end{array}$ \\
\hline $100 \%$ & Punggung & $60 \%$ \\
\hline $100 \%$ & Leher & $60 \%$ \\
\hline & Tangan & \\
\hline $80 \%$ & Pergelangan & $20 \%$ \\
\hline $0 \%$ & Lengan Atas & $0 \%$ \\
\hline $80 \%$ & Lengan Bawah & $40 \%$ \\
\hline & Kaki & \\
\hline $60 \%$ & Pergelangan Kaki & $20 \%$ \\
\hline $100 \%$ & Paha & $40 \%$ \\
\hline $100 \%$ & Lutut dan betis & $20 \%$ \\
\hline $100 \%$ & Pantat & $20 \%$ \\
\hline
\end{tabular}

Dari hasilpengambilan data tersebut, dapatdiketahuibahwaterjadipenurunankeluhankerj asetelahdiaplikasikannyafasilitaskerjabaru pada operasipenutupanbungkus. Selain dapat membuat operator lebih nyaman dalam bekerja, juga dapat mengurangi terjadinya resiko cidera pada operator.

Operasi Pembersihan Kulit (dari analisis OWAS )

Dari hasil kuesioner mengenai keluhan kerja, didapatkan hasil keluhan kerja dari operator sebelum dan sesudah perbaikan fasilitas OWAS. Adapun hasilnya dapat dilihat pada tabel 3.12 berikut.

Tabel 3.12. Perbandingan Keluhan Kerja Operasi Pembersihan Kulit (dari Analisis OWAS)

\begin{tabular}{|c|c|c|}
\hline $\begin{array}{c}\text { Persentase } \\
\text { Keluhan } \\
\text { (Fasilitas Lama) }\end{array}$ & Bagian Tubuh & $\begin{array}{c}\text { Persentase } \\
\text { Keluhan } \\
\text { (Fasilitas Baru) }\end{array}$ \\
\hline $100 \%$ & Punggung & $20 \%$ \\
\hline $100 \%$ & Leher & $60 \%$ \\
\hline & Tangan & \\
\hline $80 \%$ & Pergelangan & $40 \%$ \\
\hline $60 \%$ & Lengan Atas & $40 \%$ \\
\hline $100 \%$ & Lengan Bawah & $60 \%$ \\
\hline & Kaki & \\
\hline $100 \%$ & Pergelangan Kaki & $60 \%$ \\
\hline $40 \%$ & Paha & $20 \%$ \\
\hline $100 \%$ & Lutut dan betis & $40 \%$ \\
\hline $0 \%$ & Pantat & $0 \%$ \\
\hline
\end{tabular}

Dari data tersebutdapatdiketahuibahwaterjadipengurangank eluhan pada bagiantubuh operator setelahperbaikanfasilitas pada operasipembersihankulit.

Walaupundenganpemakaianfasilitasbarubelumdap atmenghilangkankeluhankerjadenganmaksimal, tetapisetidaknyadapatmengurangiresikocidera operator.

\subsection{Pada Perusahaan Manufaktur}

\section{Proses Produksi}


Secara umum urutan proses pembuatan antena terdapat pada gambar 3.10 sebagai berikut:

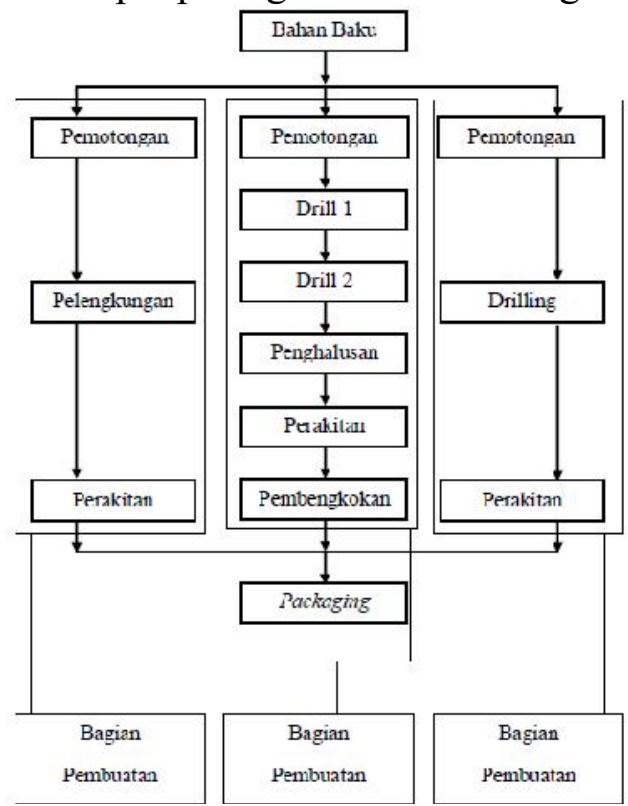

Gambar 3.10 Urutan proses pembuatan antena

PengukuranSkorRapid Upper Limbs Assessment (RULA)

Tabel 3.12. Hasil pengolahan menggunakan RULA

\begin{tabular}{|c|c|c|c|c|c|c|}
\hline no & $\begin{array}{l}\text { nama } \\
\text { bagian }\end{array}$ & $\begin{array}{c}\text { proses } \\
\text { (sebelum } \\
\text { perbaikan) }\end{array}$ & $\begin{array}{l}\text { Grand } \\
\text { Score }\end{array}$ & $\begin{array}{l}\text { Action } \\
\text { Level }\end{array}$ & $\begin{array}{l}\text { Risk } \\
\text { Level }\end{array}$ & Action \\
\hline \multirow{2}{*}{1} & \multirow{2}{*}{ balun } & rakit 1 & 4 & 2 & rendah & $\begin{array}{l}\text { mungkin } \\
\text { perlu }\end{array}$ \\
\hline & & rakil 2 & 4 & 2 & renduth & $\begin{array}{c}\text { mungkin } \\
\text { perlu }\end{array}$ \\
\hline \multirow{5}{*}{2} & \multirow{5}{*}{ boom } & drill 1 & 7 & 4 & tinggi & perlu segera \\
\hline & & drill 2 & 7 & 4 & linggi & perlusegera \\
\hline & & penghalusan & 4 & 2 & rendah & $\begin{array}{c}\text { mungkin } \\
\text { perlı. }\end{array}$ \\
\hline & & merakit 1 & 5 & 3 & sedang & perlu \\
\hline & & merakil 2 & 4 & 2 & renduh & $\begin{array}{c}\text { mungkin } \\
\text { perlu }\end{array}$ \\
\hline \multirow{3}{*}{3} & \multirow{3}{*}{$\begin{array}{c}\text { reflekto } \\
\text { r }\end{array}$} & reflektor 1 & 7 & 4 & tinggi & perlu segera \\
\hline & & reflektor 2 & 6 & 3 & sedang & perlu \\
\hline & & $r=f l e k t o r ~ 3$ & 4 & 2 & rendah & $\begin{array}{l}\text { mungkin } \\
\text { perlu }\end{array}$ \\
\hline
\end{tabular}

PengukuranSkorRapid Entire Body Assessment (REBA)

Tabel 3.13. Hasil Pemgolahan Menggunakan REBA
JUTI-UNISI (Jurnal Tenik Industri UNISI)

\begin{tabular}{|c|c|c|c|c|c|c|}
\hline No & Nama & Proses & $\begin{array}{l}\text { Grand } \\
\text { Score }\end{array}$ & $\begin{array}{l}\text { Action } \\
\text { Level }\end{array}$ & $\begin{array}{l}\text { Risk } \\
\text { Level }\end{array}$ & Action \\
\hline \multirow{2}{*}{1} & \multirow{2}{*}{ balun } & rakit 1 & 4 & 2 & Sedang & perlu \\
\hline & & rakit 2 & 4 & 2 & Sedang & perlu \\
\hline \multirow{5}{*}{2} & \multirow{5}{*}{ boom } & drill 1 & 9 & 3 & Tinggi & $\begin{array}{l}\text { perlu } \\
\text { segera }\end{array}$ \\
\hline & & drill 2 & 9 & 3 & Tinggi & $\begin{array}{l}\text { perlu } \\
\text { segera }\end{array}$ \\
\hline & & $\begin{array}{c}\text { penghalus } \\
\text { an }\end{array}$ & 8 & 3 & Tinggi & $\begin{array}{l}\text { perlu } \\
\text { segera }\end{array}$ \\
\hline & & rakit 1 & 5 & 2 & Sedang & perlu \\
\hline & & rakit 2 & 5 & 2 & Sedang & perlu \\
\hline \multirow{3}{*}{3} & \multirow{3}{*}{$\begin{array}{l}\text { reflekt } \\
\text { or }\end{array}$} & reflektor 1 & 10 & 3 & Tinggi & $\begin{array}{l}\text { perlu } \\
\text { segera }\end{array}$ \\
\hline & & reflektor 2 & 8 & 3 & Tinggi & $\begin{array}{l}\text { perlu } \\
\text { segera }\end{array}$ \\
\hline & & reflektor 3 & 7 & 2 & Sedang & perlu \\
\hline
\end{tabular}

Tabel 3.13 tentang penilaianmenggunakan REBA menunjukkanadanyabeberapa proses yang memilikitingkatresikotinggisehinggamemerlukanp erbaikandengansegera. Adapun proses yang dimaksudadalan proses drill 1, drill 2, penghalusan (pada bagian boom) dan reflektor 1 \& 2 (pada bagianreflektor). Pada proses tersebutmempunyainilaiaction level 3 dan dalammetode REBA, proses tersebutharusdilakukanperbaikandengansegera.

Perbaikandapatdilakukandenganmenyesuaikanfasi litaskerja (misal :kursi) atauposturkerjadisesuaikandenganteorireba yang menunjukkannilaiskorrendah pada anggotatubuh. Sedangkan proses yang lain mungkindiperlukanperbaikan, akantetapitidakmemilikiresiko yang tinggi.

AnalisisRekapitulasi Nilai Grand Score RULA dan REBA

AnalisisRekapitulasinilaigrand score baikmenggunakan RULA maupun REBA dilakukanuntukmengetahuinilaigrand score supayadapatdijadikanacuanuntukperbaikanposturk erja. Proses kerja yang memilikinilaigrand score tinggimerupakan proses kerja yang meilikiresikotinggi pula, sehinggaperbaikanperludilakukan.

Adapunrekapitulasinilaigrand score dapatdilihat pada tabel 4.13 berikut.

Tabel 3.14 Rekapitulasinilaigrand scoreReba dan Rula 


\begin{tabular}{|c|c|c|c|c|c|c|c|}
\hline \multirow[b]{2}{*}{$\begin{array}{l}\text { deperisic } \\
\text { mon }\end{array}$} & \multirow[b]{2}{*}{ proses } & \multicolumn{3}{|c|}{ RULA } & \multicolumn{3}{|c|}{ REBA } \\
\hline & & skor & level & $\begin{array}{l}\text { tinclakan } \\
\text { pecbaikan }\end{array}$ & $\begin{array}{c}\text { sko } \\
\text { I }\end{array}$ & level & $\begin{array}{l}\text { tindalsan } \\
\text { perbaikan }\end{array}$ \\
\hline \multirow{5}{*}{ booin } & drill 1 & 7 & 4 & perlu scacra & 9 & 3 & perlu scgera \\
\hline & drill 2 & 7 & 4 & perlu segera & 9 & 3 & perlu sepera \\
\hline & penghalusan & 1 & 2 & numugkin perlu & 8 & 3 & perlus segera \\
\hline & rakit 1 & 5 & 3 & perlu & 5 & 2 & perlu \\
\hline & rakit 2 & 4 & 2 & mungkin perlu & 4 & 2 & perlu \\
\hline \multirow{2}{*}{ bulun } & perakitan 1 & 4 & 2 & Mungkin perhu & 6 & 2 & perlu \\
\hline & Petakitat 2 & 1 & 2 & Mungkin perlu & 5 & 2 & perlu \\
\hline \multirow{3}{*}{$\begin{array}{c}\text { reflektu } \\
\mathbf{r}\end{array}$} & $\operatorname{ref} 1$ & 7 & 4 & perlu scgera & 10 & 3 & perlu segera \\
\hline & $\operatorname{ref} 2$ & 5 & 3 & perlu & 8 & 3 & perlu scacra \\
\hline & $r \in \mathbb{3} 3$ & 1 & 2 & numpgkin perlu & 7 & 2 & perlu \\
\hline
\end{tabular}

Tabel 3.14 di atasmenunjukkannilaigrand score dan action level dariposturkerja yang telah di olahmenggunakanmetode RULA dan 69 REBA. Terdapattiga proses yang memilikiskor level tinggisehinggamemerlukanperbaikan. Adapunketiga proses yang dimaksudkanadalah proses drill 1 dan drill 2 pada bagian boom dan proses pembuatanreflektor 1 pada bagianreflektor. Untukituketiga proses tersebutnantinyaakandilakukanperbaikansesuaide nganmetode RULA dan REBA sehinggamenghasilkangrand score yang lebihkecil. Skor yang lebihkecildapatmenunjukkanbahwaresiko CTD (cummulativetraume disorders) menjadilebihkecil pula. Sedangkanuntuk proses lainnyamungkinperludilakukanperbaikan, akantetapitidakmempunyainilairesiko yang tinggi. Melaluitabel 4.13 di atasdapatdibuatsimpulanbahwasannyaperbaikanp osturkerjadilakukan pada proses drill 1 dan drill 2 pada bagian boom dan proses pembuatanreflektor 1 pada bagianreflektor. Menurut Muhtar (2009) Perbaikanposturkerjadapatdilakukan pada bagianproduksi memilikitingkatresikocideratinggi.

AnalisisKeluhan dan

FasilitasKerjaSebelumPerbaikan

Tabel 3.15. Hasil Pendataan Keluhan Kerja

\begin{tabular}{|c|c|}
\hline Bagian Tubuh & Persentase (\%) \\
\hline Lengan Atas & 60 \\
\hline Lengan Bawah & 40 \\
\hline Pergelangan & 60 \\
\hline Kaki & 20 \\
\hline Leher, Punggung, Pantat & 100 \\
\hline
\end{tabular}

Berdasarkanperhitungandengan RULA dan REBA pada bagianproduksi boom, balun dan reflektorterdapat proses yang menunjukkannilaigrand score denganresikotinggi
JUTI-UNISI (Jurnal Tenik Industri UNISI) dan perludilakukanperbaikan. Adapun proses dan keadaanfasilitaskerjasebelumperbaikantersebutada lahsebagaiberikut :

1. Proses drill 1 bagian boom

a.Pengambilanbahanbakuberupaalumunium yang sudahdipotongdarigudang dan disimpandisebelahkananpekerja.

b.Bahanbakutersebutdimasukkankedalam ember yang diletakkan di ataskursisebelahkananpekerja. Melaluianalisis RULA dan REBA tinggialatdrill tidaksesuaisehinggamembentukpostur yang mempunyairesikotinggi.

c.Pekerjamengambilbahanbakutersebut di sebelahkanan dan melakukanpelubangandenganmesindrill didepannya.

d.Pengerjaanpelubanganinidilakukan di ataskursi yang adasandarannya, akantetapipekerjatidakbersandar dan terkesanmembungkuk.

e.Peletakanalumunium yang sudahdiproses di sebelahkiripekerjakedalamwadahberupakardus

2. Proses drill 2 bagian boom

a.Pengambilanbahanbakuberupaalumunium yang sudahdipotongdarigudang dan disimpandisebelahkananpekerja.

b.Bahanbakutersebutdimasukkankedalamkardus yang diletakkan di ataslantaisebelahkananpekerjadenganketinggia ntidaksesuaisehinggamembentukpostur yang mempunyairesikotinggi.

c.Pekerjamengambilbahanbakutersebut di sebelahkanan dan melakukanpelubangandenganmesindrill didepannya.

d.Pengerjaanpelubanganinidilakukan di ataskursitanpasandaran. Setelah itubahan yang sudahdiprosesdiletakkan di sebelahkiripekerja.

3. Proses drill 1 bagianreflektor

a. Proses set up mesindrill di bagianreflektor. Hal inidilakukanuntukmenentukanmatapahat yang digunakan. Terdapatduamatapahatyaknipahat diameter \pm $2 \mathrm{~mm}$ dan $\pm 5 \mathrm{~mm}$.

b. Pengambilanbahanbakuberupaalumunium yang sudahdipotongdarigudang dan diletakkan di sebelahkiripekerja.

c. Proses pelubangan pada alumuniumdenganmesindrill

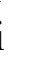

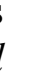


untukmendapatkanlubangtempatperakitanrefl ektor.

d. Peletakanalumunium yang sudahdiproses di sebelahkananpekerja.

\section{KESIMPULAN}

Dari analisis proses kerja, dilakukan perbaikan postur kerja dengan merancang fasilitas baru. Dari fasilitas baru tersebut kemudian dilakukan analisis kembali untuk mengetahui hasil dari perbaikan fasilitas tersebut. Setelah dilakukan perbaikan fasilitas maka dapat dibandingan nilai waktu proses. Hal ini dapat dilihat pada nilai output standar dari sebelum perbaikan dan sesudah dilakukan perbaikan faslititas mengalami peningkatan sekitar 10-20\%.

Selain itu terdapat penurunan keluhan kerja pada fasilitas yang baru sehingga dapat meminimalkan terjadinya cidera pada pekerja. Setelah perbaikan postur kerja dapat meningkatkan produktivitas kerja dari perusahaan. Selain itu juga dapat meningkatkan kenyamanan pekerja yang diketahui dengan menurunnya keluhan kerja.

\section{JUTI-UNISI (Jurnal Tenik Industri UNISI)}

\section{DAFTAR PUSTAKA}

Andriyanto, R. 2008. Identifikasi Postur Kerja Menggunakan Metode Owas Dan Analisis Konsumsi Energi Pada Proses Perontokan Padi. Universitas Muhammadiyah Surakarta.

Arisarsono, T. H. D. 2004. Perancangan Sistem Kerja Ergonomis Untuk Mengurangi Tingkat Kelelahan. Universitas Mercu Buana.

Corlett, L. M. A. E. N. 1993. Rula: A Survey Method For The Investigation Of Work-Related Upper Limb Disorders. Applied Ergonomics 1993, 24, 91-99.

Grandjean, E., 1986, Fitting The Task to The Man, Taylor \& Francis Ltd, New York

Hidayat, Taufik, 2011, Analisis Sikap Kerja untuk Meningkatkan Produktifitas dengan metode Ovako Working Posture Analysis System (OWAS), Jurusan Teknik Industri, Fakultas Teknologi Industri Universitas Islam Indonesia, Yogyakarta

KiongkoGoenawan, Jeffery, 2003, PerancanganMetode Dan FasilitasKerja Di Janfu Garment DenganPendekatanErgonomiUntukMeningkatkanPr oduktifitasPekerja, Skripsi, UKP, Surabaya.

Nur Rahman, Edwin, 2011, Perbaikan Sistem Kerja untuk Mengurangi Resiko Cidera dan Meningkatkan Produktivitas Kerja dengan Pendekatan Ergonomic Partisipatori, Jurusan Teknik Industri, Fakultas Teknologi Industri Universitas Islam Indonesia, Yogyakarta.

Nurmianto, E., 1996, Ergonomi, Konsep Dasar dan Aplikasinya, PT. Guna Widya, Jakarta.

Pratiwi, Indah. E. M., Mardiyanto, Dan Dey Yudha 2008. Analisa Postur Kerja Menggunakan Metode Rula Dan Reba. National Conference Applied Ergonomics.

Suparjo, Iwan, 2005, Analisis Postur dan Pergerakan Kerja dengan Mempergunakan Metode Occupational Repetitive Action Index (index OCRA), Jurusan Teknik Industri, Fakultas Teknologi Industri Universitas Islam Indonesia, Yogyakarta.

Sutalaksana, I.Z.,R. Angga Wisastra, J.H. Tjakraatmadja, 1979, Teknik Tata Cara Kerja, PT. Guna Widya, Jakarta. 